Original Article

\title{
Chromium supplemented carbohydrate diets for Cirrhinus mrigala: effects on body composition, gut enzyme activity and hematological parameters
}

\author{
Dietas com carboidratos suplementados com cromo para Cirrhinus mrigala: \\ efeitos sobre a composição corporal, atividade enzimática intestinal e parâmetros \\ hematológicos
}

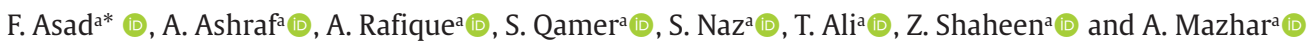 \\ ${ }^{a}$ Government College University Faisalabad, Faisalabad, Pakistan
}

\begin{abstract}
A ninety days nutritional trial was directed to explore the effects of dietary chromium on body composition, gut enzyme activity and physiological status of Cirrhinus mrigala by using G \& NG corn. Six experimental diets were prepared by using different levels of chromium chloride hexahydrate $(0,0.2,0.4 \mathrm{mg} / \mathrm{kg}$, each with G \& NG corn). For this experimental trial, 480 fingerlings, irrespective of sex were distributed in six aquariums each with replicate. Results revealed that gelatinized corn along with increasing level of $\mathrm{Cr} 2 \mathrm{Cl} 3.6 \mathrm{H} 2 \mathrm{O}$ have a positive impact upon body composition of fish. Hematology was positively correlated with chromium chloride hexahydrate supplementation in gelatinized corn. Amylase gut enzyme also showed significant $(\mathrm{P}<0.05)$ increase in group fed with chromium chloride hexahydrate supplemented diet ( $G$ corn). However, corn with chromium chloride hexahydrate supplementation did not revealed any significant impact on gut protease enzyme activity. From these results it can be concluded that both chromium chloride hexahydrate and gelatinized corn in fish feed are very beneficial to improve body composition, enzymes activity and physiological health status of fish.
\end{abstract}

Keywords: chromium, Cirrhinus mrigala, body composition, hematology and enzyme activity.

\begin{abstract}
Resumo
Um ensaio nutricional de 90 dias foi dirigido para explorar os efeitos do cromo dietético na composição corporal, atividade enzimática intestinal e estado fisiológico de Cirrhinus mrigala usando milho G \& NG. Seis dietas experimentais foram preparadas usando diferentes níveis de cloreto de cromo hexa-hidratado $(0,0,2,0,4 \mathrm{mg} / \mathrm{kg}$, cada um com milho G e NG). Para este ensaio experimental, 480 alevinos, independentemente do sexo, foram distribuídos em seis aquários, cada um com réplicas. Os resultados revelaram que o milho gelatinizado, juntamente com o aumento do nível de $\mathrm{Cr} 2 \mathrm{Cl} 3.6 \mathrm{H} 2 \mathrm{O}$, tem um impacto positivo na composição corporal dos peixes. A hematologia foi positivamente correlacionada com a suplementação de cloreto de cromo hexa-hidratado em milho gelatinizado. A enzima amilase intestinal também apresentou aumento significativo $(P<0,05)$ no grupo alimentado com dieta suplementada com cloreto de cromo hexa-hidratado (milho G). No entanto, o milho com suplementação de hexahidrato de cloreto de cromo não revelou nenhum impacto significativo na atividade da enzima protease intestinal. Desses resultados, pode-se concluir que tanto o cloreto de cromo hexa-hidratado quanto o milho gelatinizado na alimentação de peixes são muito benéficos para melhorar a composição corporal, a atividade de enzimas e o estado fisiológico de saúde dos peixes.
\end{abstract}

Palavras-chave: cromo, Cirrhinus mrigala, composição corporal, hematologia e atividade enzimática.

\section{Introduction}

To achieve higher production of fish the thing which is most essential is supplementary feed. Unluckily, the major problem in fish farming is the availability of affordable supplementary feed. Thus, the major task is the replacement of this expensive feed with low cost and locally available resources (Bangladesh, 2011). In the course of time intensive fish culture is increasing around the world. However, in Pakistan intensive farming is stumpy despite the presence of huge aquatic resources. The main reason of this low production is the expensive fish feed. The production rate could be increased with the introduction of cheap dietary sources i.e. carbohydrates.

*e-mail: far_khane@yahoo.com

Received: January 6, 2021 - Accepted: February 16, 2021 
Pakistan is rich in fish fauna, but on commercial level, only seven species of warm water and two from cold water are grown (Asad et al., 2014).

Physiological and biochemical characteristics are recognized as a useful tool in the evaluation of the metabolic functions, health status and welfare of farmed species. For growth and survival of fish species nutrition is most important. To reduce feed cost carbohydrates are utilized in fish feed formulation because carbohydrates are most economical, low cost than lipids and protein and a rich source of energy (Asad et al., 2020). Factors that affect the carbohydrate utilization efficiency in dietary regimes of cultured fish species are carbohydrate origin, dietary carbohydrate content in the diets, physical state, and molecular complexity. Related to the latter factor, it appears that in order to utilize simple versus complex carbohydrates, most fish species use polysaccharides and oligosaccharides better than mono and disaccharides (Azaza et al., 2020). Carbohydrates are the cheapest dietary source of energy and normally used in formulated diet for protein sparing. With the higher amylase activity and also with greater number and affinity of insulin receptors omnivorous warm-water fishes show an efficient utilization of higher levels of carbohydrates in comparison to carnivorous cold water-fishes. Content of carbohydrate in diet, main origin, molecular complexity and physical state are the major factors that have an impact on the efficiency of carbohydrate utilization in dietary pattern of fish species. In discussion of molecular complexity of carbohydrate i.e. complex versus simple utilization, it was found that oligosaccharides and polysaccharides were utilized better by most of the species than mono and disaccharides. Although, some species use simple carbohydrates more efficiently rather than complex, these include gilt head sea bream (Sparus aurata), the rainbow trout (Oncorhynchus mykiss), the grass carp (Ctenopharyngodon idella), etc. (Polakof et al., 2012).

In aquaculture, dietary carbohydrate used at top priority due to its benefits i.e. high availability and low cost, mainly for omnivorous and herbivorous fish. The use of carbohydrate could be improved by the process of gelatinization; however, its excessive use might result in cellular changes and metabolic stress as naturally fish adapted to low carbohydrate.

\section{Materials and Methods}

Execution of this nutritional trial was held in research lab, Department of Zoology, Government College University, Faisalabad, Pakistan.

\subsection{Test specie and experimental design}

Cirrhinus mrigala was selected as an experimental fish species. Fingerlings (480) of this species were purchased from fish seed hatchery, Staina road Faisalabad, Pakistan. Acclimatization (for one week) was done before the commencement of the trial; stocked in aquaria with 29L water capacity, weaned on control diet (32\% CP). On daily basis water quality parameters were monitored and found within acceptable range following standard method (dissolved oxygen; 5.2-7.3 mg/L, pH; 7.5-8.5 and temperature; $28-31^{\circ} \mathrm{C}$ ) (APHA, 1985). After acclimatization 480 fingerlings of uniform size were arbitrarily dispersed in six experimental groups each with one replicates (T1 G/0 $0 \mathrm{Cr}_{2} \mathrm{Cl}_{3} \cdot 6 \mathrm{H}_{2} \mathrm{Omg} / \mathrm{kg}, \mathrm{T} 2 \mathrm{NG} / 0 \mathrm{Cr}_{2} \mathrm{Cl}_{3} \cdot 6 \mathrm{H}_{2} \mathrm{Omg} / \mathrm{kg}$ (control diet), T3G $/ 0.2 \mathrm{Cr}_{2} \mathrm{Cl}_{3} \cdot 6 \mathrm{H}_{2} \mathrm{Omg} / \mathrm{kg}$, T4 NG0.2 $2 \mathrm{Cr}_{2} \mathrm{Cl}_{3} \cdot 6 \mathrm{H}_{2} \mathrm{Omg} / \mathrm{kg}$, $\mathrm{T} 5 \mathrm{G} / 0.4 \mathrm{Cr}_{2} \mathrm{Cl}_{3} \cdot 6 \mathrm{H}_{2} \mathrm{O} \mathrm{mg} / \mathrm{kg}$ and T6 NG/0.4 $\mathrm{Cr}_{2} \mathrm{Cl}_{3} \cdot 6 \mathrm{H}_{2} \mathrm{Omg} / \mathrm{kg}$ ).

\subsection{Experimental diets and Feeding protocol}

Basic diet ingredients were bought from local market of Faisalabad. Six experimental diets were prepared by using corn (gelatinized \& non-gelatinized) with different levels of chromium chloride hexahydrate $(0,0.2$ and $0.4 \mathrm{Cr}_{2} \mathrm{Cl}_{3} \cdot 6 \mathrm{H}_{2} \mathrm{O} \mathrm{mg} \mathrm{Kg}{ }^{-1}$ ). To make dough, corn flour was mixed with almost $80 \%$ of water (v/w) and maximum gelatinization (25\%) was attained by leaving it in an autoclave for about an hour at $120{ }^{\circ} \mathrm{C}$. This gelatinized corn flour with all diet ingredients (casein, gelatin, corn flour, cellulose, sunflower oil, vitamin premixes and Butylated Hydroxy Toluene) were then pulverized to pass through $5 \mathrm{~mm}$ sieve size. Dough was formed from all these ingredients by mixing them for 10 min with $10-12 \%$ water with the addition of fish oil gradually while mixing and then steamed for $10 \mathrm{~min}$ (Lovell, 1989). Pellets of $2 \mathrm{~mm}$ diameter were prepared by using hand pelletizer, dried in oven at $60{ }^{\circ} \mathrm{C}$ for 24 hour . Cirrhinus mrigala fingerlings were fed on experimental diet twice daily at $4 \%$ of live wet body weight for 90 days

\subsection{Proximate analysis}

The dried samples of feed ingredient (corn), test diets and body meat were separately homogenized with mortar and pestle and were chemically analyzed following standard method of AOAC (1990) dry matter (DM) by drying in oven for 12 hours at $105^{\circ} \mathrm{C}$; crude lipid by chloroform methanol extraction technique through 10454 soxtec system HTz; ash analysis was done in electric muffle furnace(Eyela-TMF 3100); crude protein (CP) by microkjeldahl investigation. Percent free extract and gross energy was calculated by following Formulas 1 and 2 (Henken et al., 1986):

$$
\begin{aligned}
& \text { NFE } \%=100-(\text { crude protein } \%+\text { crude fat } \%+\text { moisture } \%) \\
& \text { GE }(\text { Kcal } / g)=(5.64 \times \text { protein } \%)+(9.44 \times \text { lipids } \%)+(4.11 \times \text { NFE } \%)
\end{aligned}
$$

\subsection{Hematological analysis}

After trial completion, fish from experimental groups were sacrificed and blood was drawn from caudal vain in vials (rinsed with heparin) which was used for hematological analysis i.e. hemoglobin, RBCs and WBCs count. HGB and hematocrits were measured by cyanmet hemoglobin method (Drabkin, 1945). RBCs and WBCs were measured with a Burker hemocytometer. RBCs indices were calculated following Greer et al. (2014) (Formulas 3 to 5).

$$
\mathbf{M C V}=\frac{\text { Hematocrit }}{\mathrm{RBC}}
$$




$$
\begin{aligned}
& \mathbf{M C H}=\frac{\mathrm{HGB}}{\mathrm{RBC}} \\
& \mathbf{M C H C}=\frac{\text { HGB }}{\text { Hematocrit }}
\end{aligned}
$$

\subsection{Enzyme activity}

At the completion of trial, to measure enzyme activity, supernatants of gut and liver were prepared by sacrificing the fish from each group. For this, the liver and gut was homogenized in distilled water and then centrifuged at $5000 \mathrm{rpm}$ for 20 minutes (whole procedure done at $-4^{\circ} \mathrm{C}$ ). Then supernatants were collected and stored at $-20^{\circ} \mathrm{C}$ till required. Activity of two enzymes (amylase and protease) was analyzed. Protease activity was determined following casein hydrolysis method by Walter (1984) while amylase activity was determined by starch hydrolysis following Somogy-Nelson colorimetric method.

\subsection{Statistical analysis}

Highly significant differences between gelatinized and non-gelatinized corn diets with different levels of chromium chloride hexahydrate were tested by one way analysis of variance (ANOVA) while comparison of means was performed by Tukey's significant difference test; considered significant at p $>0.05$ (Snedecor and Cochran, 1991).

\section{Results}

\subsection{Body composition}

Body composition parameters are the key indicator of the physiological status of fish as well as feed composition and feeding rates. Results revealed that gelatinized corn along with increasing level of $\mathrm{Cr} 2 \mathrm{Cl} 3.6 \mathrm{H} 2 \mathrm{O}$ have a positive impact upon body composition of fish (Table 1). Fish fed on test diet T3\& T5 (Gelatinized) showed highest percentage of dry matter and it was significantly different from all other groups, as determined by ANOVA $(\mathrm{P}<0.05)$. While ash retention, crude lipid, crude protein and gross energy was maximum in fish fed on test diet -T5 (Gelatinized) from other groups ( $\mathrm{P}>0.05)$.

\subsection{Hematology}

Chromium chloride hexahydrate along with gelatinized corn showed a significant impact on fish hemoglobin content as determined by ANOVA $(\mathrm{P}<0.05)$. Fish fed with diet T5 ( $\mathrm{G}, 0.4 \mathrm{Cr} 2 \mathrm{Cl} 3.6 \mathrm{H} 2 \mathrm{O})$ showed significantly higher hemoglobin content $(8.5 \pm 0.55 \mathrm{~g} / \mathrm{dl})$ compared to the other groups while least hemoglobin content $(6.3 \pm 0.20 \mathrm{~g} / \mathrm{dl})$ was shown by fish fed with diet T4. Experimental group of fish fed with diet $\mathrm{T} 5$ showed significantly higher WBCs $\left(11.65 \pm 0.25 \times 10^{3} / \mu \mathrm{L}\right)$ while least WBCs was calculated in experimental group of fish with diet $\mathrm{T} 1\left(6.90 \pm 0.30 \times 10^{3} / \mu \mathrm{L}\right)$. Regarding RBCs, experimental group fed with diet T5 exhibited significantly higher value than other groups that showed non-significant differences $(\mathrm{P}>0.05)$ while least value for RBCs count was calculated in group fed with diet T2. Data related to hematocrit content in experimental groups depicts results similar to hemoglobin content i.e. significantly higher HCT content in group fed on diet T1 with all other groups showed non-significant differences from each other while least HCT content was shown by fish fed with diet T4.

In case of RBCs indices, $\mathrm{MCV}$ (mean cellular volume)was recorded highest ( $168.00 \pm 10.00 \mathrm{fL}$ ) in group fed with diet $\mathrm{T} 2$ and it showed highly significant differences from other groups while lowest value for MCV (121.00 $\pm 7.00 \mathrm{fL})$ was calculated in group fed with diet T4and it showed highly non-significant differences from other groups. Similar results pattern was recorded for $\mathrm{MCH}$ (mean cellular hemoglobin). Regarding the results of MCHC (mean cellular hemoglobin concentration), experimental group fed with diet T4 showed significantly higher value $(47.50 \pm 1.50 \mathrm{pg})$ of MCHC while group fed with diet T1 showed significantly lower value $(32.85 \pm 0.85 \mathrm{pg}$ ) of MCHC (Table 2 ).

\subsection{Enzyme activity}

The secretion of enzymes in fish is mainly dependent upon diet's composition and nature on which fish is feeding. Results revealed that corn type had no effect on liver amylase activity of Cirrhinus mrigala while chromium chloride hexahydrate supplementation showed a highly significant impact as determined by ANOVA $(\mathrm{P}<0.05)$. Group fed with diet T5 $(G)$ showed significantly higher liver amylase activity while least liver amylase activity was recorded in group fed with diet T1. Feeding on G corn, significantly maximize the gut amylase activity $(\mathrm{P}<0.05)$.

\begin{tabular}{|c|c|c|c|c|c|}
\hline Dietary Treatments & Dry matter (\%) & Ash (\%) & Crude lipid (\%) & Crude protein (\%) & $\begin{array}{l}\text { Gross Energy } \\
\text { (Kcal/g) }\end{array}$ \\
\hline $\mathrm{T} 1$ (G) $0 \mathrm{mg} / \mathrm{kg} \mathrm{CrCl} \cdot 6 \mathrm{H}_{2} 0$ & $94.10 \pm 0.10 \mathrm{BC}$ & $86.05 \pm 0.05 \mathrm{BC}$ & $26.25 \pm 0.25 \mathrm{DE}$ & $28.10 \pm 0.60 \mathrm{~B}$ & $572.81 \pm 2.33 \mathrm{C}$ \\
\hline $\mathrm{T} 2(\mathrm{NG}) 0 \mathrm{mg} / \mathrm{kg} \mathrm{CrCl}_{3} \cdot 6 \mathrm{H}_{2} \mathrm{O}$ & $95.15 \pm 0.15 \mathrm{ABC}$ & $87.05 \pm 0.15 \mathrm{ABC}$ & $24.25 \pm 0.25 \mathrm{E}$ & $32.83 \pm 0.02 \mathrm{~A}$ & $572.59 \pm 1.36 \mathrm{C}$ \\
\hline $\mathrm{T} 3(\mathrm{G}) 0.2 \mathrm{mg} / \mathrm{kg} \mathrm{CrCl}_{3} \bullet 6 \mathrm{H}_{2} \mathrm{O}$ & $97.25 \pm 0.25 \mathrm{~A}$ & $84.50 \pm 1.00 \mathrm{C}$ & $32.00 \pm 1.00 \mathrm{C}$ & $33.06 \pm 1.81 \mathrm{~A}$ & $621.08 \pm 3.75 B$ \\
\hline $\mathrm{T} 4(\mathrm{NG}) 0.2 \mathrm{mg} / \mathrm{kg} \mathrm{CrCl} \cdot 6 \mathrm{H}_{2} \mathrm{O}$ & $93.25 \pm 0.25 C$ & $88.50 \pm 1.50 \mathrm{~A}$ & $26.75 \pm 0.75 \mathrm{D}$ & $34.98 \pm 0.78 \mathrm{~A}$ & $579.61 \pm 3.83 C$ \\
\hline T5 (G) $0.4 \mathrm{mg} / \mathrm{kg} \mathrm{CrCl}_{3} \bullet 6 \mathrm{H}_{2} \mathrm{O}$ & $97.25 \pm 0.25 \mathrm{~A}$ & $89.50 \pm 0.50 \mathrm{AB}$ & $38.45 \pm 0.45 \mathrm{~A}$ & $35.10 \pm 0.57 \mathrm{~A}$ & $658.08 \pm 4.29 \mathrm{~A}$ \\
\hline T6 (NG) $0.4 \mathrm{mg} / \mathrm{kg} \mathrm{CrCl} \bullet_{3} \cdot 6 \mathrm{H}_{2} \mathrm{O}$ & $95.50 \pm 1.50 \mathrm{AB}$ & $85.00 \pm 1.10 \mathrm{C}$ & $35.35 \pm 0.35 \mathrm{~B}$ & $33.43 \pm 0.38 \mathrm{~A}$ & $632.06 \pm 4.88 \mathrm{~B}$ \\
\hline
\end{tabular}

Table 1. Comparison of means of muscle composition of Cirrhinus mrigala fed on different experimental diets. 
Similarly, significant relations was found among corn type and gut amylase activity. Lowest gut amylase activity was recorded in group fed with NG corn without chromium chloride hexahydrate supplementation (Figure 1).

Supplementation of chromium chloride hexahydrate decreases the protease activity in liver; highest liver protease activity was recorded in group fed with $\mathrm{G}$ corn without chromium chloride hexahydrate supplementation in diet (T1), with non- significant differences. While least liver protease activity was recorded in group fed with

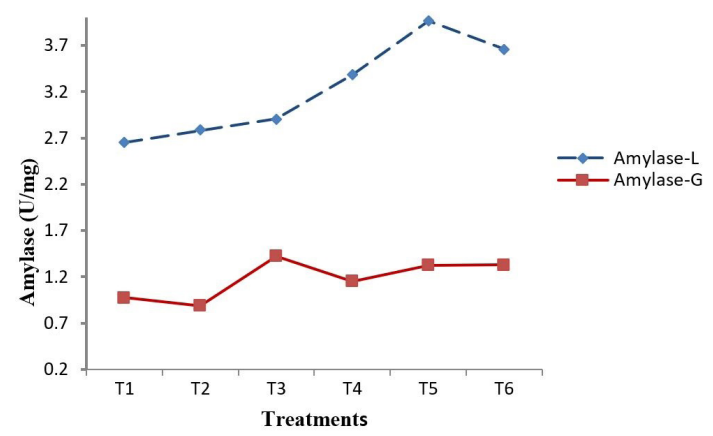

Figure 1. Amylase activity in liver and gut of Cirrrhinus mrigala fed on experimental diets. Data represented as mean $\pm \mathrm{SE}$.

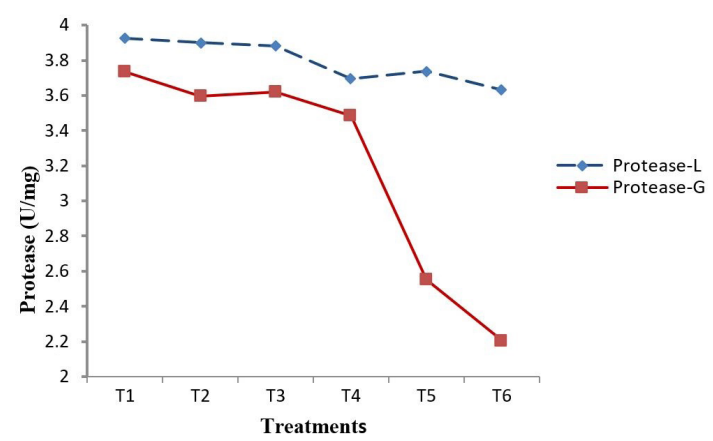

Figure 2. Protease activity in liver and gut of Cirrrhinus mrigala fed on experimental diets. Data represented as mean $\pm \mathrm{SE}$.
G corn along with highest level of chromium chloride hexahydrate (T6). Similar pattern of results were shown in gut protease activity (Figure 2).

\section{Discussion}

In case of body composition, results revealed that gelatinized corn along with chromium chloride hexahydrate had positive impact on dry matter deposition in group fed with diets T3 and T5. Present findings are in agreement with the work of Asad et al. (2017) who reported that dry matter deposition was observed maximum at level of $0.3 \mathrm{mg} / \mathrm{kg}$ chromium chloride hexahydrate. Consistent results were reported with Mehrim (2014) who concluded that highest dry matter deposition was at level $400 \mathrm{ug} / \mathrm{kg}$ in dorsal muscle of Oreochromis niloticus. Ash retention, crude lipid, crude protein and gross energy showed maximum values at level of $\mathrm{G} / 0.4 \mathrm{mg} / \mathrm{kg}$ chromium chloride hexahydrate. These findings are in accordance with Asad et al. (2017) who recorded the highest crude lipid deposition, ash retention and gross energy at level of $0.5 \mathrm{mg} / \mathrm{kg}$ chromium chloride hexahydrate along with gelatinized corn. These results were also supported by Khabade (2015) who stated that chromium chloride hexahydrate had beneficial impact upon protein retention in fish body composition. The reason is that both gelatinized corn and chromium chloride hexahydrate positively affect the fish body composition because these are involved in enhancing the fish' metabolism and digestibility (Magzoub et al., 2010).

Hematological indices are very important to assess the physiological status of fish feeding on diet supplemented with metal. These hematological changes in fish blood, fed on metal supplemented diet, used to measure the significant impact and appropriate concentration of these dietary metals (Azarin et al., 2012). Maximum hemoglobin concentration, RBCs and WBCs values were calculated maximum in group of fish fed with diet T5 $\left(\mathrm{G} / 0.4 \mathrm{Cr}_{2} \mathrm{Cl}_{3} \cdot 6 \mathrm{H}_{2} \mathrm{Omg} / \mathrm{kg}\right)$. Similar results were also reported by Hedayati and Ghaffari (2013); stated significant increase in hematological parameters in silver carp. Increase in WBCs count was also reported by Singh (1995). This increase of blood parameters in group fed with chromium supplemented diet may be due to agitation effect of chromium which enhances the $\mathrm{Hb}$ and $\mathrm{RBCs}$ production.

Table 2. Comparison of means of approximate hematological analysis in Cirrhinus mrigala fed on different experimental diets.

\begin{tabular}{|c|c|c|c|c|c|c|c|}
\hline Dietary Treatments & $\mathrm{Hb}(\mathrm{g} / \mathrm{dl})$ & $\begin{array}{c}\text { WBCs } \\
\left(\mathbf{x} 10^{3} / \mu \mathrm{L}\right)\end{array}$ & $\begin{array}{c}\text { RBCs } \\
\left(\times 10^{6} / \mu \mathrm{L}\right)\end{array}$ & $\begin{array}{c}\text { HCT (PCV)\% } \\
\text { Packed cell } \\
\text { volume }\end{array}$ & $\operatorname{MCV}(\mathbf{f L})$ & $\mathrm{MCHC}(\mathrm{pg})$ & $\mathrm{MCH}(\mathrm{g} / \mathrm{dl})$ \\
\hline $\mathrm{T1}$ (G) $0 \mathrm{mg} / \mathrm{kg} \mathrm{CrCl} \cdot 6 \mathrm{H}_{2} 0$ & $7.45 \pm 0.15 \mathrm{AB}$ & $6.90 \pm 0.30 \mathrm{C}$ & $1.65 \pm 0.03 \mathrm{AB}$ & $27.15 \pm 0.75 \mathrm{~A}$ & $164.5 \pm 0.5 \mathrm{AB}$ & $32.85 \pm 0.85 C$ & $55.00 \pm 3.30 \mathrm{~A}$ \\
\hline $\mathrm{T} 2(\mathrm{NG}) 0 \mathrm{mg} / \mathrm{kg} \mathrm{CrCl}{ }_{3} \cdot 6 \mathrm{H}_{2} \mathrm{O}$ & $7.5 \pm 0.150 \mathrm{AB}$ & $10.9 \pm 0.40 \mathrm{AB}$ & $1.350 \pm 0.030 \mathrm{~B}$ & $22.50 \pm 0.50 \mathrm{~B}$ & $168.00 \pm 10 \mathrm{~A}$ & $39.50 \pm 0.50 \mathrm{~B}$ & $56.50 \pm 2.50 \mathrm{~A}$ \\
\hline $\mathrm{T} 3(\mathrm{G}) 0.2 \mathrm{mg} / \mathrm{kg} \mathrm{CrCl}_{3} \cdot 6 \mathrm{H}_{2} \mathrm{O}$ & $6.600 \pm 0.20 \mathrm{~B}$ & $10.20 \pm 0.1 \mathrm{AB}$ & $1.45 \pm 0.04 \mathrm{AB}$ & $19.50 \pm 0.50 \mathrm{~B}$ & $136 \pm 8.5 \mathrm{ABC}$ & $45.00 \pm 1 \mathrm{AB}$ & $50.50 \pm 1.5 \mathrm{AB}$ \\
\hline $\mathrm{T} 4(\mathrm{NG}) 0.2 \mathrm{mg} / \mathrm{kg} \mathrm{\textrm {CrCl } _ { 3 }} \cdot 6 \mathrm{H}_{2} \mathrm{O}$ & $6.300 \pm 0.20 \mathrm{~B}$ & $10.10 \pm 0.20 \mathrm{~B}$ & $1.550 \pm 0.1 \mathrm{AB}$ & $19.00 \pm 1.00 \mathrm{~B}$ & $121.00 \pm 7.0 \mathrm{C}$ & $47.50 \pm 1.50 \mathrm{~A}$ & $38.00 \pm 2.0 \mathrm{C}$ \\
\hline $\mathrm{T} 5$ (G) $0.4 \mathrm{mg} / \mathrm{kg} \mathrm{CrCl} \cdot 6 \mathrm{H}_{2} 0$ & $8.550 \pm 0.55 \mathrm{~A}$ & $11.65 \pm 0.25 \mathrm{~A}$ & $1.750 \pm 0.05 \mathrm{~A}$ & $22.50 \pm 0.50 \mathrm{~B}$ & $127.5 \pm 6.5 \mathrm{BC}$ & $40.00 \pm 1.00 \mathrm{~B}$ & $42.50 \pm 0.5 \mathrm{BC}$ \\
\hline $\mathrm{T6}$ (NG) $0.4 \mathrm{mg} / \mathrm{kg} \mathrm{CrCl}_{3} \cdot 6 \mathrm{H}_{2} 0$ & $7.45 \pm 0.35 \mathrm{AB}$ & $11.1 \pm 0.2 \mathrm{AB}$ & $1.700 \pm 0.05 \mathrm{~A}$ & $22.00 \pm 1.00 \mathrm{~B}$ & $131 \pm 1.5 \mathrm{ABC}$ & $39.50 \pm 1.50 \mathrm{~B}$ & $48.0 \pm 1.0 \mathrm{ABC}$ \\
\hline
\end{tabular}


It can be supposed that fish may be exposed to gill injury due to chromium toxicity. This in turn, results in deficiency of oxygen, enhancing RBCs production to reduce the affect. Increase in number of WBCs count may be due to immunological response for antibodies' production to overcome stress caused by the chromium. However contradictory results were reported by Al-Ghanim (2011); concluded reduction in RBCs, $\mathrm{Hb}$, and WBCs in the blood of Cyprinus carpio. Hematocrit and RBCs indices (MCV, MCH and $\mathrm{MCHC}$ ) were calculated maximum in groups fed on diet without chromium chloride hexahydrate supplementation. However dissimilar findings were reported by Carvalho and Fernandes (2006).

Activity of digestive enzymes has been investigated in many omnivorous and herbivorous species as it has major role in polysaccharides' breakdown into small sugar chains. In fish, role of amylase enzyme is glycogen digestion which is an energy source for animal tissues. Highest liver and gut protease activity was recorded in group of fish fed with diet T1. These results correlate with the work of Kumar et al. (2006) who reported decrease in protease activity in Labeo rohita with increasing chromium level. However, conflicting results were reported by Xiong et al. (2010) who found higher value of protease in foregut of catfish with chromium supplemented diet. Maximum liver amylase activity was recorded in group fed with diet T5. Similar results were reported by Mohapatra et al. (2003) stated maximum liver amylase activity with increasing chromium and gelatinization level in Labeo rohita's diet. Maximum gut amylase activity was recorded in group fed with diet T3. These findings are in agreement with Ghosh et al. (2001) who stated maximum gut amylase activity in group fed with chromium supplemented diet in comparison to group with non-supplemented diet. This may be due to maximum consumption of carbohydrate in gelatinized form in the presence of chromium (enhance absorption) to fulfill the energy requirement (Kumar et al., 2006). However, contradictory results were recorded by Huang et al. (2013) stated that chromium supplementation has no significant impact on amylase activity of fish.

\section{Conclusion}

From present study it can be concluded that diet supplemented with gelatinized corn and $\mathrm{Cr} 2 \mathrm{Cl} 3.6 \mathrm{H} 2 \mathrm{O}$ was beneficial for Cirrhinus mrigala as it improves fish body composition, digestibility and hematology. So fish production could be improved by using chromium chloride hexahydrate along with gelatinized corn in feed. However, more research needed in this filed like how much gelatinized degree of corn is required.

\section{Acknowledgements}

This research work was accomplished with the funds provided by Higher Education Commission (HEC, Pakistan) under NRPU Project No. 20-5134/NRPU/R\&D/HEC/2014.

\section{References}

AL-GHANIM, K.A., 2011. Impact of nickel (Ni) on hematological parameters and behavioral changes in Cyprinus carpio (common carp). African Journal of Biotechnology, vol. 10, no. 63, pp. 1386013866. http://dx.doi.org/10.5897/AJB11.1893.

AMERICAN PUBLIC HEALTH ASSOCIATION - APHA, 1985. Standard methods for the examination of water and wastewater. 20th ed. Washington: APHA, pp. 205-290.

ASAD, F., NASEEM, N., ASHRAF, A., ALI, T. and BEHZAD, A., 2017. Chemical composition and growth performance of Labeo rohita under the influence of Chromium chloride hexahydrate marker. International Journal of Biosciences, vol. 10, no. 1, pp. 186-194. http://dx.doi.org/10.12692/ijb/10.1.186-194.

ASAD, F., QAMER, M. and TAHIR, N., 2014. Apparent nutrient digestibility assessment and influence of gelatinized and non-gelatinized corn starch based diet in Labeo rohita. Journal of Aquaculture Research \& Development, vol. 5, no. 5, pp. 250. http://dx.doi.org/10.4172/2155-9546.1000250.

ASAD, F., QAMER, S., ASHRAF, A., RAFIQUE, A., SHAHEEN, Z., NISAR, A. and JAVAID, S., 2020. Apparent nutrient digestibility of carbohydrate (corn) in Cirrhinus mrigala under the influence of chromium chloride hexahydrate. Brazilian Journal of Biology = Revista Brasileira de Biologia, vol. 80, no. 3, pp. 518-522. http:// dx.doi.org/10.1590/1519-6984.214176. PMid:31576931.

ASSOCIATION OF OFFICIAL ANALYTICAL CHEMISTS - AOAC, 1990. Official methods of analysis. Rockville: AOAC, vol. 1, pp. 201-205.

AZARIN, H., IMANPOUR, M.R. and RAJABPOUR, M., 2012. Effect of sub-lethal levels of copper sulfate on some hematological parameters of Rutilusfrisiikutum fingerlings. Global Veterinaria, vol. 9, pp. 479-485.

AZAZA, M.S., SAIDI, S.A., DHRAIEF, M.N. and EL-FEKI, A., 2020. Growth performance, nutrient digestibility, hematological parameters, and hepatic oxidative stress response in juvenile Nile tilapia, Oreochromis niloticus, fed carbohydrates of different complexities. Journal Animals., vol. 10, no. 10, pp. 1913. http:// dx.doi.org/10.3390/ani10101913. PMid:33086506.

BANGLADESH. Department of Fisheries - DoF, 2011. National Fish Week 2011 Compendium. Dhaka. (in Bengali).

CARVALHO, C.S. and FERNANDES, M.N., 2006. Effect of temperature on copper toxicity and haematological responses in the neotropical fish Prochilodusscofa at low and high pH. Aquaculture, vol. 251, no. 1, pp. 109-117. http://dx.doi. org/10.1016/j.aquaculture.2005.05.018.

DRABKIN, D.I., 1945. Crystallographic and optical properties of human hemoglobin: a proposal for the standarization of hemoglobin. The American Journal of Medicine, vol. 209, pp. 268-270.

GHOSH, K., CHAKRABORTY, K., SEN, S.K. and RAY, A.K., 2001. Effect of thermostable bacterial a-amylase on growth and feed utilization in rohu, Labeo rohita (Hamilton) juveniles. Israeli Journal of Aquaculture - Bamidgeh, vol. 53, pp. 101-109.

GREER, J.P., ARBER, D.A. and GLADER, B., 2014. Wintrobe's clinical hematology. 13th ed. Philadelphia: Wolters Kluwer Health, pp. 237-241.

HEDAYATI, A. and GHAFFARI, Z., 2013. Effect of mercuric chloride on some hematological, biochemical parameters in silver carp (Hypophthalmichthy smolitrix). International Journal of Veterinary Medicine Research E Reports, vol. 50, pp. 1-11.

HENKEN, A.M., LUCAS, H., TIJSSEN, P.A.T. and MACHIELS, M.A.M., 1986. A comparison between methods used to determine the energy content of feed, fish and faeces samples. Journal 
of Aquaculture, vol. 58, no. 3-4, pp. 195-201. http://dx.doi. org/10.1016/0044-8486(86)90085-2.

HUANG, J., XIONG, B., CHEN, J., WANG, Q., ZHU, Y., SHI, B. and XU, W., 2013. Activity and distribution of diegestive enzymes for paddlefish (Polyodonspathula). Huazhong Nongye Daxue Xuebao, vol. 32, pp. 110-115.

KHABADE, S., 2015. Study of gut contents of major carps for their food habits from Sidddhewadi lake of Tasgaontahsil of Sangli district Maharashtra. International Journal of Fisheries and Aquatic Studies, vol. 2, no. 4, pp. 1-4.

KUMAR, S., SAHU, N.P., PAL, A.K., CHOUDHURY, D. and MUKHERJEE, S.C., 2006. Non-gelatinized corn supplemented with achromium at sub-optimum protein level enhances the growth of Labeo rohita (Hamilton) fingerlings. Aquaculture Research, vol. 37, no. 3, pp. 284-292. http://dx.doi.org/10.1111/j.1365-2109.2005.01434.x.

LOVELL, T., 1989. Nutrition and feeding of fish (Vol. 260). New York: Van Nostr and Reinhold.

MAGZOUB, M.B., AL-BATSHAN, H.A., HUSSEIN, M.F., AL-MUFARRE, S.I. and AL-SAIADY, M.Y., 2010. The effect of of source and level of dietary chromium supplementation on performance, chemical composition and some metabolic aspects in hybrid tilapia fish (Oreochromis niloticus x O. aureus). Research Journal of Biological Sciences, vol. 5, no. 2, pp. 164-170. http://dx.doi. org/10.3923/rjbsci.2010.164.170.

MEHRIM, A.I., 2014. Physiological, biochemical and histometric responses of Nile tilapia (Oreochromis niloticus L.) by dietary organic chromium (chromium picolinate) supplementation. Journal of Advanced Research, vol. 5, no. 3, pp. 303-310. http:// dx.doi.org/10.1016/j.jare.2013.04.002. PMid:25685497.

MOHAPATRA, M., SAHU, N. and CHAUDHARI, A., 2003. Utilization of gelatinized carbohydrate in diets of Labeo rohita fry. Aquaculture Nutrition, vol. 9, no. 3, pp. 189-196. http://dx.doi. org/10.1046/j.1365-2095.2003.00243.x.

POLAKOF, S., PANSERAT, S., SOENGAS, J.L. and MOON, T.W., 2012. Glucose metabolism in fish: a review. Journal of Comparative Physiology. B, Biochemical, Systemic, and Environmental Physiology, vol. 182, no. 8, pp. 1015-1045. http://dx.doi. org/10.1007/s00360-012-0658-7. PMid:22476584.

SINGH, M., 1995. Haematological responses in a freshwater teleost Channa punctatus to experimental copper and chrom-ium poisoning. Journal of Environmental Biology, vol. 16, no. 4, pp. 339-341.

SNEDECOR, G.W. and COCHRAN, W.G., 1991. Statistical methods. 8th ed. Ames: Lowa State Univ. Press, 503 p.

WALTER, H. E., 1984. Proteases and their inhibitors. 2. 15. 2 Method with haemoglobin, casein and azocoll as substrate. Methods of enzymatic analysis, pp. 270-277.

XIONG, F., CHEN, D. and DUAN, X., 2010. Threatened fishes of the world: Gymnocypris przewalskii (Kessler, 1876) (Cyprinidae: Schizothoracinae). Environmental Biology of Fishes, vol. 87, no. 4, pp. 351-352. http://dx.doi.org/10.1007/s10641-010-9609-x. 